\title{
Association between PrP genotypes and selected growth traits of Hungarian Merino and German Mutton Merino rams (Short Communication)
}

\author{
BARBARA NAGY' ${ }^{1}$, ISTVÁN ANTON N', LÁSZLÓ SÁFÁR² , LÁSZLÓ FÉSÜS ${ }^{1}$ and ATTILA ZSOLNAI ${ }^{1}$ \\ 'Research Institute for Animal Breeding and Nutrition, Herceghalom, Hungary, ${ }^{2}$ Hungarian Sheepbreeders' \\ Association, Budapest, Hungary
}

\section{Abstract}

In sheep, susceptibility to scrapie is associated with the prion protein (PrP) gene polymorphism. In this study the association between selected growth traits (daily weight gain from birth to weaning and in farm fattening performance test, as well as body weight at one and two years) and PrP genotypes ARR/ARR, ARR/XXX and XXX/XXX (XXX representing $A H Q, A R Q, A R H$ or $V R Q$ ) has been investigated in Hungarian Merino ( $n=286)$ and German Mutton Merino ( $n=215)$ rams. No significant association was found among the studied growth traits and the PrP genotypes in the Hungarian Merino breed. In case of a group of German Mutton Merino rams lamb daily gain was significantly $(P \leq 0.05)-$ but in a small extent - associated with PrP genotype, which influenced the daily gain values by $9.6 \%$.

Keywords: prion protein (PrP) genotypes, growth traits, sheep, Merino

\section{Zusammenfassung}

\section{Beziehungen zwischen PrP Genotypen und einigen Wachstumsmerkmalen von Ungarischen und Deutschen Merinoböcken (Kurzmitteilung)}

Beim Schaf ist das Vorkommen von Scrapie verbunden mit dem Prion-Protein (PrP) Genpolymorphismus. In vorliegendem Beitrag werden die Beziehungen zwischen ausgewählten Wachstumsmerkmalen, wie der täglichen Zunahme von Geburt bis zum Absetzen, der Gewichtszunahme während eines 40-tägigen Stichprobentestes sowie dem Körpergewicht im Alter von einem bzw. zwei Jahren und den PrP Genotypen ARR/ARR, ARR/XXX und XXX/XXX (XXX repräsentiert AHQ, ARQ, ARH oder VRQ) untersucht. Erfasst wurden Böcke der Ungarischen Merino $(n=286)$ und Deutschen Merino ( $n=215)$ Schafe. Bei den Ungarischen Merinoböcken konnten keine signifikanten Beziehungen zwischen den erfassten Wachstumsmerkmalen und den PrP Genotypen nachgewiesen werden. Bei den deutschen Merinobocklämmern aus Importen war die tägliche Zunahme geringfügig aber signifikant mit den PrP Genotypen verbunden.

Schlüsselwörter: Prion Protein (PrP) Genotypen, Wachstumsmerkmale, Schaf, Merino 


\section{Introduction}

Scrapie is a fatal, infectious, neurodegenerative disease of sheep and goats (PRUSINER 1991, DRÖGEMÜLLER et al. 2001). In sheep a well defined polymorphism of the PrP gene has been demonstrated at codons 136 ( $A$ to $V), 154(\mathrm{R}$ to $\mathrm{H}), 171(\mathrm{Q}$ to $\mathrm{R}, \mathrm{H})$ determining five allelic variants ( $A R R, A H Q, A R Q, A R H$ and $V R Q$ ) which can be related to scrapie susceptibility or resistance (WISNIEWSKA et al. 2006).

According to Commission Regulation (EC) No. 100/2003, using genotype information, each member country should carry out breeding programmes to increase the frequency of the ARR allele and to reduce that of those alleles which are associated with increased disease risk. This selection might result in changes of certain production and/or reproduction traits, and might induce strong selection pressure on ovine chromosome 13.

Several studies have been carried out to estimate the possible influence of the individual PrP genotypes on various quality and production traits. PROPOKOVÁ et al. (2002), DE VRIES et al. (2004), GERNAND et al. (2005) and CASELLAS et al. (2007) conducted studies for some selected growth traits and could not demonstrate significant PrP genotype effects. BRANDSMA et al. (2004) demonstrated small negative, significant genotype effect on 135 days body weight. A simulation has also focused on possible genetic loss interval if selection is starting for the ARR variant (WING-YOUNG et al. 2007).

The aim of the study was to estimate the relationship of PrP genotypes with production traits (daily weight gain from 1 to 135 days, on farm fattening performance from 150 to 185 days, as well as body weight at 1 and 2 years) in the Hungarian Merino and German Mutton Merino breeds.

\section{Material and methods}

\section{Animals}

501 rams - 286 Hungarian Merinos (HM) and 215 German Mutton Merinos (GMM) - from 98 breeding herds were included in the study. Among German Mutton Merino rams import and home bred rams were used, as well. Rams were selected for the analysis since they can easily spread favourable characteristics of the selected growth traits on the population, and because the Hungarian scrapie breeding programme primarily focuses on the genotyping of rams. Rams included in this study were born between the years of 1993 and 2005.

The first data set included production data (available in the herd books of the Hungarian Sheepbreeders Association): lamb daily gain from birth to weaning (between 60-80 days) ( $\mathrm{g} /$ day), and in the 40 days long farm fattening performance test after weaning ( $\mathrm{g} /$ day) as well as body weights $(\mathrm{kg})$ at 1 and 2 years of age, respectively. The second data set included the PrP genotypes (genotyping was performed at the Research Institute for Animal Breeding and Nutrition, Herceghalom, Hungary).

\section{PrP genotyping}

The DNA isolation was done from whole blood. In the first PCR reaction 266 bp part of PrP gene was amplified. After purification the amplified fragment was used as a template in 
the second reaction containing primers with various lengths (40-60 mers, designed right beside the SNP sites responsible for prion genotypes in question) and labeled ddNTPs. Finally, the genotype assessment of the one-base elongated primers were based on capillary-electrophoretic separation on ABIPrism 310 Genetic Analyzer (Applied Biosystems, USA) followed by the application of Genotyper and Microsoft Excel softwares. This method was detailed and described elsewhere (ZSOLNAl et al. 2003).

\section{Statistical analysis}

Using SPSS 14.0 software the method of univariate analysis of variance and estimated marginal means was applied to appraise the contingent correlations and relations of the PrP genotypes and growth trait data. The GLM - general linear model - model included the following effects: the three PrP genotype groups (ARR/ARR, ARR/XXX and XXX/XXX) was used as fixed effects and the growth traits (lamb growth, on farm fattening performance, 1 and 2 year weight) as dependent factors. The significance of these factors was proved by least square difference method. Correlation and regression analysis were also performed by SPSS software.

\section{Results and discussion}

The favourable ARR/ARR genotypes occurred at middle-size frequency in both breeds (about $25 \%$ in $\mathrm{HM}$ and $20 \%$ in GMM) (Table 1). The analysis of the means and standard deviations of examined growth traits in Hungarian Merino rams revealed no significant differences regarding the three genotype classes. However, as a general tendency, sheep with ARR/XXX genotype seemed to be superior in lamb growth, 1 and 2 year weight (Table 2).

Table 1

Genotype frequencies and number of animals

Genotypenfrequenz und Tierzahlen

\begin{tabular}{lccc}
\hline Breeds & ARR/ARR & ARR/XXX & XXX/XXX \\
\hline Hungarian Merino $(n=286)$ & $24.82 \%(n=71)$ & $55.59 \%(n=159)$ & $19.58 \%(n=56)$ \\
German Mutton Merino $(n=215)$ & $20.00 \%(n=43)$ & $63.25 \%(n=136)$ & $16.74 \%(n=36)$ \\
\hline
\end{tabular}

Table 2

Descriptive statistic of the growht traits in Hungarian Merino

PrP Genotypen und Wachstumsmerkmale ungarischer Merino

\begin{tabular}{lrrrrrrrr}
\hline \multirow{2}{*}{ Traits } & \multicolumn{2}{c}{ ARR/ARR } & \multicolumn{2}{c}{ ARR/XXX } & \multicolumn{2}{c}{ XXX/XXX } & \multicolumn{2}{c}{ Total } \\
& Mean & \multicolumn{1}{c}{ SD } & Mean & \multicolumn{1}{c}{ SD } & Mean & \multicolumn{1}{c}{ SD } & Mean & \multicolumn{1}{c}{ SD } \\
\hline Lamb growth, g/day & 373.00 & 83.07 & 376.72 & 72.44 & 358.10 & 67.76 & 372.31 & 74.57 \\
Large scale fattening, g/day & 348.13 & 67.47 & 347.25 & 76.12 & 355.15 & 52.92 & 348.81 & 69.62 \\
1 year body weight, kg & 73.83 & 9.71 & 74.45 & 10.24 & 71.39 & 8.76 & 73.72 & 9.87 \\
2 year body weight, kg & 88.24 & 13.04 & 90.52 & 11.89 & 89.55 & 14.61 & 89.75 & 12.72 \\
\hline SD standard deviation & & & & & & & &
\end{tabular}

Among the home bred German Mutton Merino rams we have not found significant differences between the genotypes and the investigated traits. In the import group significant differences were observable in lamb daily gain and the genotype classes. In the import group the large scale fattening data were not available, because the country 
does not use it as characteristic of meat performance. Sheep not carrying the ARR allele were superior in all traits (Table 3 ).

Deviations from the expected genotype frequencies was only found in German Mutton Merino rams (data not shown), so two separate - a home bred and an import subgroups were used in the calculations. Deviation from the Hardy-Weinberg equilibrium was detectable only in the home bred group (Table 4).

The difference between the observed and expected genotype frequency values proved to be significant. The possible explanation of the disequilibrium could be the selection on multiple traits at the same time.

Table 3

Descriptive statistic of the growth traits in import German Mutton Merino

PrP Genotypen und Wachstumsmerkmale deutscher Merino

\begin{tabular}{lcccccccc}
\hline \multirow{2}{*}{ Traits } & \multicolumn{2}{c}{ ARR/ARR } & \multicolumn{2}{c}{ ARR/XXX } & \multicolumn{2}{c}{ XXX/XXX } & \multicolumn{2}{c}{ Total } \\
& Mean & SD & Mean & SD & Mean & SD & Mean & SD \\
\hline Lamb growth, g/day & $360.90^{*}$ & 50.36 & $374.00^{*}$ & 65.60 & $422.24^{*}$ & 65.61 & 383.14 & 66.57 \\
1 year weight, $\mathrm{kg}$ & 80.82 & 12.50 & 83.93 & 11.16 & 88.53 & 11.77 & 84.53 & 11.60 \\
2 year weight, $\mathrm{kg}$ & 107.45 & 14.31 & 105.00 & 13.41 & 116.71 & 15.89 & 108.10 & 14.76 \\
\hline
\end{tabular}

SD standard deviation, * ${ }^{*}$ shows the significant relationship at level 0.05

Table 4

The expected (in brackets) and the observed frequencies of PrP genotypes in German mutton merino rams Erwartete (in Klammern) und nachgewiesene PrP Genotypenfrequenz bei deutschen Merinoböcken

\begin{tabular}{lccccc}
\hline Breeds & Number & ARR/ARR & ARR/XXX & XXX/XXX & $\times 2$ \\
\hline German Mutton Merino import rams & 73 & $15(11)$ & $21(17)$ & $36(45)$ & 4.077 \\
German Mutton Merino home bred rams & 142 & $42(32)$ & $70(91)$ & $29(19)$ & 12.13 \\
\hline
\end{tabular}

Hungarian Merino and home bred German Merino populations did not show significant associations between the PrP genotypes and growth traits. Only the import group of German Mutton Merino rams not carrying ARR haplotype performed significantly $(P<0.05)$ better in case of daily gain values (Table 3 .) but the interaction was found to be week (correlation coefficient was 0.291 ) and the genotype was responsible for the total daily gain variance in $9.6 \%$.

The negative association of daily gain values with ARR haplotype might be the effect of selection of the ARR allele and it might be the proof of the genetic loss, as a consequence of breeding for scrapie resistance (WING-YOUNG et al. 2007). This could explain why the effect was detectable among those import animals which came from a country where selection procedure has longer history than in Hungary.

Our findings are also in accordance with BRANDSMA et al. (2004) where small negative effect was found on 135 days weight correlated with the ARR allele.

Since the found effect of ARR haplotype on daily gain is very low and the genetic improvement is coming back in long term (WING-YOUNG et al. 2007), temporary stagnancy or temporary decreasing in genetic improvement is the price for having a scrapie resistant livestock in the future. 


\section{References}

Brandsma JH, Janss LLG, Visscher AH (2004) Association between PrP genotypes and littersize and 135 days weight in Texel sheep. Livest Prod Sci 85, 59-64

Casellas J, Caja G, Bach R, Francino O, Piedrafita J (2007) Association analyses between the prion protein locus and reproductive and lamb traits in Ripollesa sheep. J Anim Sci 85, 592-7

De Vries F, Borchers N, Hamann H, Drögemüller C, Reinecke S, Lüpping W, Distl O (2004) Association between the prion protein genotype and performance traits of meat breeds of sheep. Vet Record $155,140-3$

Drögemüller C, Leeb T, Distl O (2001) Breeding for resistance to scrapie: Detection of polymorphismus in the prion protein gene in GErman sheep breeds. Arch Tierz $44 \mathrm{SI}, 280-7$

Gernand E, Lenz H, Moog U, Waßmuth R (2005) Association between prion-protein-haplotypes and yield traits of station and field tested sheep. Arch Tierz 48, 383-95 [in German]

Prokopová L, Lewis RM, Dingwall WS, Simm G (2002) Scrapie Genotype. A correlation with Lean Growth Rate. 7th World Congress on Genetics Applied to Livestock Production August 19-23 2002 Montpellier, France, Session 13: Disease resistance, Communication No. 13-44

Prusiner SB (1991) Molecular biology of prion disease. Science 252, 1515-22

Wing-Young NM, Lewis RM, Boulton K, Villanueva B (2007) Predicting the consequences of selecting on PrP genotypes on PrP frequencies performance and inbreeding in commercial meat sheep populations. Genet Sel Evol 39, 711-29

Wisniewska E, Lühken G, Mroczkowski S, Erhardt G (2006) Prion protein (PrP) gene polymorphisms, and breeding for resistance to scrapie in Polish Merino sheep. Arch Tierz $49 \mathrm{SI}, 365-71$

Zsolnai A, Anton I, Kühn C, Fésüs L (2003) Detection of single-nucleotide polymorphisms coding for three ovine prion protein variants by primer estension assay and capillary electrophoresis. Electrophoresis 24, 634-8

Received 19 January 2009, accepted 5 October 2009.

Corresponding author:

BARBARA NAGY

email: barbara.nagy@quintiles.com

Research Institute for Animal Breeding and Nutrition, 2053 Herceghalom, Hungary 